\title{
FURTHER STUDIES OF THE TABANID压 OF TRINIDAD, B. W. I.
}

\section{By J. Bequaert}

\section{Harvard Medical School and School of Public Health, Boston, Mass.}

The publication of my list of Trinidad Tabanidæ a few years ago (1940, Bull. Ent. Res., 30, pp. 447-453) induced several entomologists to a more intensive study of these flies. Dr. E. McC. Callan submitted for identification two lots, including all specimens in the Department of Entomology of the Imperial College of Tropical Agriculture. More recently Dr. Raymond C. Shannon, of the International Health Division, The Rockefeller Foundation, forwarded to me many specimens obtained by him and his associates in the course of their studies on malaria. The result is most gratifying and has induced me to draw up a revised list of the species known from the island. This was the more necessary because recent careful work on the Panamanian fauna by Dr. G. B. Fairchild has resulted in certain corrected identifications and names. Some of these changes were decided upon in personal discussion with Dr. Fairchild, and most of them have since been published by him. None of the information given in my earlier paper is repeated here, unless it called for correction.

The number of known Trinidad Tabanidæ has risen now from 23 to 31 species, 9 species being added. One of the species of the earlier list (Tabanus ochrophilus) was dropped, as the specimen on which the record was based is not now available for study and was no doubt misidentified. The following changes in nomenclature were made. The species formerly listed as Chrysops auroguttata is now called Chrysops pallidefemorata Kröber. Stibasoma dyridophorum becomes a synonym of $S$. mallophoroides. The older name T. limonus is applied to the species formerly called $T$. viridis. In accordance with G. B. Fairchild's recent work, T. amplifrons is used for the species I called $T$. trilineatus and $T$. vittiger subsp. guatemalanus for 
the females formerly called $T$. carneus; while T.appendiculatus is considered a synonym of $T$. lineola var. carneus.

Two species of Tabanidae are now known from Tobago: Tabanus amplifrons and T. leucaspis, both common in Trinidad.

In my earlier paper a brief comparison was drawn between the tabanid faunæ of Trinidad, the Antilles, and continental South America. This was somewhat amplified in my monograph of the Tabanidæ of the Antilles (1940, Rev. de Entomologia, 11, p. 271-272). The conclusions reached at the time are merely confirmed by recent additions. The purely South American character of the Trinidad tabanid fauna remains beyond dispute. All nine genera of the revised list are found on the continent. This is true also of the nine subgenera here included in the genus Tabanus, some of these groups being given generic rank by recent authors (Stenotabanus, Leucotabanus, Chlorotabanus, etc.). The 31 species likewise all occur on the American mainland, where most of them are widely distributed. On the other hand only four of the nine Trinidad genera are represented in the Antilles (Chrysops, Lepiselaga, Dichelacera, Tabanus); while of the nine subgenera of Tabanus, five occur in Trinidad as well as in the Antilles (Chelotabanus, Bellardia, Chlorotabanus, Macrocormus and Stenotabanus). Of the 31 Trinidad species, only five are definitely known from the Antilles: Chrysops variegata, Lepiselaga crassipes, Tabanus hookeri, T. vittiger ( $=$ T. truquii of my Antillean monograph) and $T$. lineola. ( $T$. ferrifer has been recorded doubtfully from Barbados). These five species are widely distributed throughout tropical America, $T$. lineola occurring even in the Nearctic Region.

1. Chrysops variegata (Degeer).

2. Chrysops tristis (Fabricius).

3. Chrysops fulviceps Walker ( $=$ C. aurofasciatus Kröber).

4. Chrysops pallidefemorata Kröber $(=C$. auroguttatus var. pallidefemoratus Kröber, 1930, Zoolog. Anzeiger, 90, p. 72, figs. 9-10; o ; Trinidad).

Lezard Swamp, female (R. C. Shannon); Caroni Swamp, female (R. C. Shannon).

These two specimens agree with Kröber's figures of the head, antenna (partly drawn) and wing pattern of var. pallidefemoratus, not with those of his typical auroguttatus (Ibid., p. 71, 
figs. 6 and 8 ). The second tergite of the abdomen bears a small median apical pale spot.

A renewed study of these specimens and of some other material in our collections has led me to separate pallidefemorata as a distinct species. The frons is considerably broader than in auroguttata; the second antennal segment is relatively shorter and the first somewhat swollen; the hyaline area in the fourth and fifth posterior cells touches the discal cell; there is no trace of a hyaline spot near the base in the first submarginal cell; and the apical dark streak of the wing is more deeply notched at the base by the hyaline area, so that its apical portion appears widened. The three females from Quintana Roo, Mexico, which I called C. incisa in my paper on the Yucatan Tabanidæ (1932, Jl. New York Ent. Soc., 39, for 1931, p. 535) were really $C$. pallidefemorata, so that the species appears to be widely distributed.

The specimens which I listed from Trinidad under C. auroguttata in my earlier paper (1940, p. 448) are not now available, so that I am unable to place them under either that species or $C$. pallidefemorata. There is even a possibility that the Trinidad cotype of auroguttata was really a pallidefemorata and that Kröber's drawings of auroguttata were made from the Colombia cotype (both cotypes are at the British Museum). For this reason I omit provisionally the true auroguttata from the Trinidad list. The female from Costa Rica (Carillo), which I reported in 1940, was Kröber's true auroguttata and this is also true of the Panama records published by Pechuman (1937, Rev. de Entomologia, 7, p. 136) as C. auroguttata var. pallidefemorata, and by G. B. Fairchild (1942, Proc. Ent. Soc. Washington, 44, p. 4) as $C$. incisa.

Whether Chrysops incisus Macquart (1845, Mém. Soc. R. Sci. Agric. Arts Lille, for 1844, p. 172, Pl. IV, figs. 12-12a; $q$; "New Grenada") was C. auroguttata Kröber, C. pallidefemorata Kröber or some other species (? meloena Hine) appears impossible to decide, unless Macquart's type could be found. The description is vague (the yellow stripes on the sides of the mesonotum are not mentioned) and the drawings are too crude to be reliable.

5. Chrysops bulbicornis Ad. Lutz.

St. Augustine, 2 females (W. Cook; one of the specimens had 
been named $C$. laeta, a species not known from Trinidad); St. Augustine, male, allotype (A. M. Adamson); Penal, female (R. C. Shannon); also 3 females from Trinidad, without more definite locality (Stanton Crawford). The species also occurs in Bolivia (Monte S. Pablo).

The markings of body and wings are somewhat as in C. loeta (Fabricius); but $C$. bulbicornis is readily recognized by the conspicuously swollen first antennal segment and the prominent, conical callosities of the face. In addition, the female has rows of lateral spots on tergites 3 to 6 , which tend to fuse into lateral stripes, and the apical black streak of the wing fills the marginal cell completely (the hyaline area not crossing the second longitudinal vein).

Male (undescribed). Antennæ as in female, the first segment conspicuously swollen, pear-shaped, both in profile and from above; facial callosities very prominent, cone-shaped; eyes broadly contiguous. Head, including palpi and first two antennal segments, honey-yellow (third segment lacking). Thorax black, covered with black and gray hairs; scutellum and pleura slightly brownish; mesonotum on each side with a prominent yellow stripe. Legs mostly honey-yellow, with black pile; coxæ more brownish. Abdomen brownish-black; dorsum narrowly golden-yellow along extreme sides, with a median row of small, triangular yellow spots on tergites 2 to 5 (more rounded off on tergite 2) and small marginal lateral spots on tergites 3 to 5 (free from the median spot on tergites 3 and 4 ; narrowly connected on tergite 5). Wing much as in the male of C. loeta (see Kröber, 1925, Konowia, 4, Pl. III), but apical black streak filling entire marginal cell and anal cell without distinct hyaline streak (though with a slightly paler area). Length, $7 \mathrm{~mm}$.; of wing, $6.5 \mathrm{~mm}$.

6. Esenbeckia prasiniventris (Macquart).

St. Augustine, female, the prey of a bembicid wasp, Rubrica surinamensis (Degeer) (E. McC. Callan); Maraval, female (Imper. Coll. Trop. Agric.).

7. Lepiselaga crassipes (Fabricius).

Pt. Fortia, female (R. C. Shannon).

Widely distributed in the Greater Antilles, Central and South America. 
8. Selasoma tibiale (Wiedemann).

9. Stibasoma fulvohirtum (Wiedemann).

Balandra Bay, female (W. Cook); Brasso, female, biting man (E. McC. Callan); Cumato, female (R. C. Shannon); Point Gourde, female, biting man (E. McC. Callan); Rio Claro, female (R. C. Shannon).

10. Stibasoma mallophoroides (Walker) (= Stibasoma dyridophorum Knab).

Balandra, female (E. McC. Callan).

Hine, who examined the type of Walker's species at the British Museum, wrote in his manuscript notes: "Type o very much like $S$. dyridophorum Knab; wings almost exactly the same; the discal spot is hyaline in mallophoroides and extends into second basal cell, as is the case in Knab's species. It would seem that the variation known to exist in this genus would bring the two together." This synonymy was accepted by me in 1940 (Rev. de Entomologia, 11, p. 272). S. mallophoroides was described from the Amazon region, Brazil.

11. Dichelacera ochracea Hine.

Valencia, 2 females, biting man (E. McC. Callan).

12. Tabanus (Chelotabanus) discifer Walker, 1850 (= Tabanus albomaculatus Walker, 1854).

Arima, female (E. McC. Callan); Rio Claro, female (E. McC. Callan); Tamano, female (R. C. Shannon).

The species is known also from Brazil (Pará; San Alberto on the Rio Branco in the State of Amazonas), Dutch Guiana and Venezuela. T. discifer was based on the female, T. albomaculatus on the male. Kröber (1931, Zool. Anzeig., 96, p. 53) reported it from Trinidad and recognized that discifer and albomaculatus were the two sexes of one species. I was inclined at one time to regard Tabanus guttigaster Kröber (1934) (=T. guttiventris Kröber, 1929) as the same species and used that name in my paper on Antillean Tabanidæ (1940, Rev. de Entomologia, 11, p. 272); but this synonymy is uncertain and $T$. discifer is, in any case, the older valid name.

13. Tabanus (Chelotabanus) ferrifer Walker.

St. Augustine, many females and males (J. T. Gonzalves; A. C. Salazar; E. McC. Callan; A. M. Adamson; Ruth O'Connor; M. D. French-Mullen; D. K. Kevan); also one female 
as prey of the bembecid wasp, Rubrica surinamensis (Degeer). El Dorado Village, female (M. V. Beattie; named T. ferrifer by the late Major E. E. Austen); Nariva Swamp, female (R. C. Shannon); Mundo Nuevo, female (R. C. Shannon); Tamano, female (R. C. Shannon); Siparia, female (R. C. Shannon).

According to Dr. McC. Callan, this is one of the commonest horseflies at St. Augustine, the males being found in ones and twos sitting in sunny places from about 8 A.M. to 4 P.M.

\section{Tabanus (Bellardia) xipe Kröber.}

St. Augustine, male, October 22, 1937 (A. M. Adamson); Tamano, female (R. C. Shannon).

Male (undescribed). - Differs from the male of $T$. ferrifer in size, extent of the velvety-black spot of the scutellum, markings of abdomen, color of wings, presence of a long appendix at the fork of the third longitudinal vein, and shape of antennæ In all these characters it agrees with the female of xipe. The eyes are entirely bare and divided into an upper zone of enlarged and a lower zone of small facets.

Dr. Shannon sketched the eye of the female as purple with three green cross-bands, the upper one rather broad but short, the lower one very broad and somewhat narrowed outwardly, the middle one much narrower than the others and somewhat wavy.

According to G. B. Fairchild (1942, Psyche, 49, p. 8) Lophotabanus Szilády (1926) is not subgenerically separable from Bellardia Rondani (1863), an opinion with which I concur.

15. Tabanus (Phæotabanus) semiflavus Kröber.

Princes Town, female (R. C. Shannon).

This specimen agrees with two females I have seen from Brazil (Curralinho, State of Pará). The species was first described from Venezuela.

16. Tabanus (Chlorotabanus) mexicanus Linnæus.

Tamano, female (R. C. Shannon).

17. Tabanus (Cryptotylus) unicolor Wiedemann.

Mayaro, female (D. K. Kevan); Tamano, 2 females (R. C. Shannon).

18. Tabanus (Cryptotylus) limonus Townsend (= Ommallia viridis Enderlein).

G. B. Fairchild (1940, Rev. de Entomologia, 11, pp. 720- 
722 ) established what appears to be the correct synonymy of this species. It is known at present from Mexico, Guatemala, Honduras, Panama, Colombia, Trinidad and northern Brazil.

At one time I referred the Trinidad specimens to Tabanus luteoflavus Bellardi (see J. Beqaert, 1940, Rev. de Entomologia, 11, p. 272); but this was erroneous. As for the green male from Paraguay which I mentioned at the close of the discussion of $T$. viridis, it has now been recognized as that of Tabanus (Cryptotylus) princeps Brèthes.

19. Tabanus (Leucotabanus) leucaspis Wiedemann.

Princes Town, female (R. C. Shannon); Saut d'Eau Bay, female, biting man (E. McC. Callan); St. Augustine, 2 females (Ruth O'Connor); Tacarigua, several females (T. H. Khan); Tamano, female (A. M. Adamson); Maracas Valley, female (M. V. Beattie). Other females merely labeled Trinidad (Stanton Crawford).

A common species in Trinidad. I have also seen one female from Speyside, Tobago (biting man) (E. McC. Callan).

20. Tabanus (Macrocormus) sorbillans Wiedemann.

St. Augustine, 4 females (A. M. Adamson; E. McC. Callan) and 2 males (Ruth O'Connor); Tamano, female (R. C. Shannon).

According to a sketch by Dr. Shannon, the eye of the female is purple with 2 rather narrow green cross-bands in life.

\section{Tabanus (Stenotabanus) maculifrons Hine.}

Blanchisseuse, female (R. C. Shannon).

This remarkable little horsefly was originally described from Guatemala (1907, Ohio Naturalist, 8, p. 222; $q$ ). I have taken a female in Colombia (Caney River near Restrepo, Int. Meta) and G. B. Fairchild found it in Panama. The eye, which I observed in life and which was also sketched by Dr. Shannon, is pale purplish with two moderately broad, unconnected bluishgreen cross-bands: one shorter, starting from the frontal callus; the other in the lower third, curved upward at the outer end.

\section{Tabanus (Neotabanus) hookeri Knab.}

St. Augustine, several females (D. J. Billes; E. McC. Callan; D. K. Kevan); also one female as prey of Rubrica surinamensis (Degeer) and one male as prey of Stictia signata (Linnæus) (E. McC. Callan); El Dorado Village, female (M. V. Beattie). 
23. Tabanus (Neotabanus) johannesi Fairchild (1942, Ann. Ent. Soc. America, 35, p. 164, pl. 1, fig. 6; ㅇ ô ).

Nariva Swamp, female (R. C. Shannon).

This specimen was compared with a paratype from Brazil The species is known also from Paraguay.

24. Tabanus (Neotabanus) amplifrons Kröber (= Tabanus trilineatus J. Bequært, 1940; not of Latreille).

St. Augustine, several females and males, one male taken at light (E. McC. Callan; A. M. Adamson; P. C. Atteck). Tamano, female (R. C. Shannon); Toco, 2 males (R. C. Shannon); El Dorado Village, 2 males (M. V. Beattie); San Fernando, male (C. B. Williams).

It is the species which I called T. trilineatus in my 1940 paper. As shown by G. B. Fairchild (1942, Ann. Ent. Soc. America, 35, p. 178), Latreille's T. trilineatus appears to be unrecognizable. T. amplifrons is known also from Texas, Guatemala, Panama, Colombia, Venezuela and the Amazon Basin of Brazil. In Trinidad it is one of the most common horseflies. According to Dr. E. McC. Callan, the males are often observed in numbers, sometimes even in hundreds, flying and hovering over roadways from about 6 A.M. to 9 A.M.

25. Tabanus (Neotabanus) vittiger var. guatemalanus Hine (= Tabanus carneus J. Bequært, 1940; not of Bellardi).

Moruga, female (R. C. Shannon). The females from Trinidad and Siparia, Trinidad, referred to T. carneus in my 1940 paper were guatemalanus; but the Trinidad male of carneus was that of T. lineola var. carneus.

The var. guatemalanus is widely distributed in Central and northern South America.

In a former paper (1940, Rev. de Entomologia, 11, pp. 272 and 352), I identified T. vittiger Thomson (1868) with Tabanus truquii Bellardi (1859); but Dr. G. B. Fairchild does not agree with this. He regards Bellardi's species as unrecognizable, although possibly the same as Tabanus amplifrons Kröber. He also treats the Antillean specimens of $T$. vittiger as a distinct race, which he calls subsp. caymanicus (1942, Ann. Ent. Soc. America, 35, p. 180); but the distinction between guatemalanus and caymanicus seems to be too finely drawn and based mainly on distributional data, not on reliable characters. 
26. Tabanus (Neotabanus) angustivitta Kröber.

Nariva Swamp, female (R. C. Shannon).

G. B. Fairchild saw this species from Mexico, Guatemala, Panama, Colombia, Venezuela, British Guiana, Brazil, Ecuador, Peru, Paraguay and northern Argentina.

27. Tabanus (Neotabanus) fumatipennis Kröber.

G. B. Fairchild, who discusses this species at some length (1942, Ann. Ent. Soc. America, 35, p. 162), saw specimens from Trinidad, as well as from Costa Rica, Panama, Brazil and British Guiana.

28. Tabanus (Neotabanus) lineola var. carneus Bellardi ( $=T a$ banus appendiculatus Hine).

Yarra River, male (R. C. Shannon); Rio Claro, female, biting mule (E. McC. Callan); St. Augustine, female, prey of Rubrica surinamensis (Degeer) (E. McC. Callan); Maracas Bay, female (P. C. Atteck); Mayaro, female (D. K. Kevan). The specimens from Port of Spain and St. Augustine, listed as $T$. appendiculatus in my 1940 paper, were also T. lineola var. carneus.

The var. carneus is a common horsefly in Trinidad. It occurs over most of the Neotropical Region, from Mexico to Paraguay and southern Brazil. No other form of $T$. lineola is known thus far from Trinidad.

Tabanus ochrophilus of my 1940 paper is omitted here. It is extremely doubtful that the specimen I saw from Trinidad (not now available for study) was Ad. Lutz's species, which was perhaps only a variant of $T$. lineola var. carneus, as suggested by G. B. Fairchild (1942, Ann. Ent. Soc. America, 35, p. 175).

The difficult group of trivittate American species, grouped under Neotabanus, has recently been revised by G. B. Fairchild and his conclusions are here accepted. The following key of the seven forms definitely known from Trinidad will replace what I wrote in 1940 (Bull. Ent. Res., 30, pp. 452-453).

1. Subcallus bare and shiny in both sexes .................. 2 .

Subcallus pollinose and dull in both sexes .................... 3.

2. Subcallus honey-yellow. Wing hyaline. Mid-dorsal stripe of a series of triangles; lateral stripes broken up into oblique spots. Female: frons about three times as high as wide, slightly narrowed below. Male: upper twothirds of eye hairy and with the facets much larger than those of lower third. Length, 9 to $12 \mathrm{~mm}$. .................... T. hookeri.

Subcallus dark drown to black. Wing slightly smoky. Mid-dorsal stripe of narrow truncate triangles; lateral stripes of a series of short streaks in line. 
Female: frons at least five times as high as greatest width, slightly narrowed below. Length, 9 to $12 \mathrm{~mm}$. (Male unknown) ...... T. fumatipennis.

3. Female: frons less than three times as high as wide and nearly parallel-sided; frontal callus at least as wide as high and nearly as wide as frons. Lateral

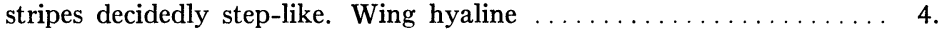

Female: frons at least three times as high as wide (usually much higher); in doubtful cases narrowed below; frontal callus as high as wide or higher and narrower than frons. Lateral stripes usually regular. Fore coxæ and most femora largely pale or yellowish $\ldots \ldots \ldots \ldots \ldots \ldots \ldots \ldots \ldots \ldots \ldots \ldots$

4. Fore coxæ and most femora largely black. Scutellum black. Mid-dorsal stripe a slender even line. Female: frontal callus dark brown to black. Male: upper half of eye hairy, but with the facets only slightly larger than those of lower half (the line of demarkation between the two types not clearly defined). Length, $11 \mathrm{~mm}$.

T. johannesi.

Female: fore coxæ and most femora pale; scutellum reddish; mid-dorsal stripe a series of contiguous triangles; frontal callus yellowish-brown. Length, 11 to $14 \mathrm{~mm}$. (Male unknown) .......... angustivitta.

5. Grayish; abdominal stripes broad and quite even, covered with chalky-white hair. Wing hyaline. Female: frons nearly parallel-sided; frontal callus grownish, only slightly higher than wide. Male: upper half of eye hairy, but with the facets only slightly larger than those of lower half (the two areas not clearly defined). Length, 12 to $15 \mathrm{~mm}$. ...... $T$. amplifrons.

Grayish to yellowish-brown; abdominal stripes covered with grayish-white or yellowish hair. Female: frons narrowed below; frontal callus usually decidedly higher than wide

6. Wing hyaline. Female: frons somewhat less than four times as high as greatest width; frontal callus large, yellowish-brown. Male: upper two-thirds of eye hairy and with the facets much larger than those of lower third. Length, 12 to $14 \mathrm{~mm}$. .............. $T$. vittiger var. guatemalanus.

Wing somewhat clouded, at least along the veins. Female: frons at least four times as high as greatest width; frontal callus rather small, dark brown to black. Male: upper two-thirds of eye bare, but with the facets much larger than those of lower third. Length, 12 to $14 \mathrm{~mm}$.

T. lineola var. carneus.

\section{Diachlorus scutellatus Macquart.}

Trinidad, without more definite locality, female (W. Urich). This insect was sent to the U. S. Nat. Mus. and determined by Dr. Alan Stone, who sent it to me for study. The species is known also from French Guiana, British Guiana and Brazil. 30. Diachlorus curvipes (Fabricius).

Nariva Swamp, female (R. C. Shannon). The species is known with certainty from Panama, Colombia (Muzo, Dept. Boyaca), British Guiana, French Guiana, Venezuela, and Brazil. Surcouf's citation of "Uruguay" was an error for Paraguay; but the occurrence in Paraguay is doubtful.

\section{Acanthocera marginalis Walker.}

Diego Martin, female (D. J. Billes); Morne Bleu, 2,700 ft. female, biting man (E. McC. Callan); Talparo, female, biting man (E. McC. Callan). 

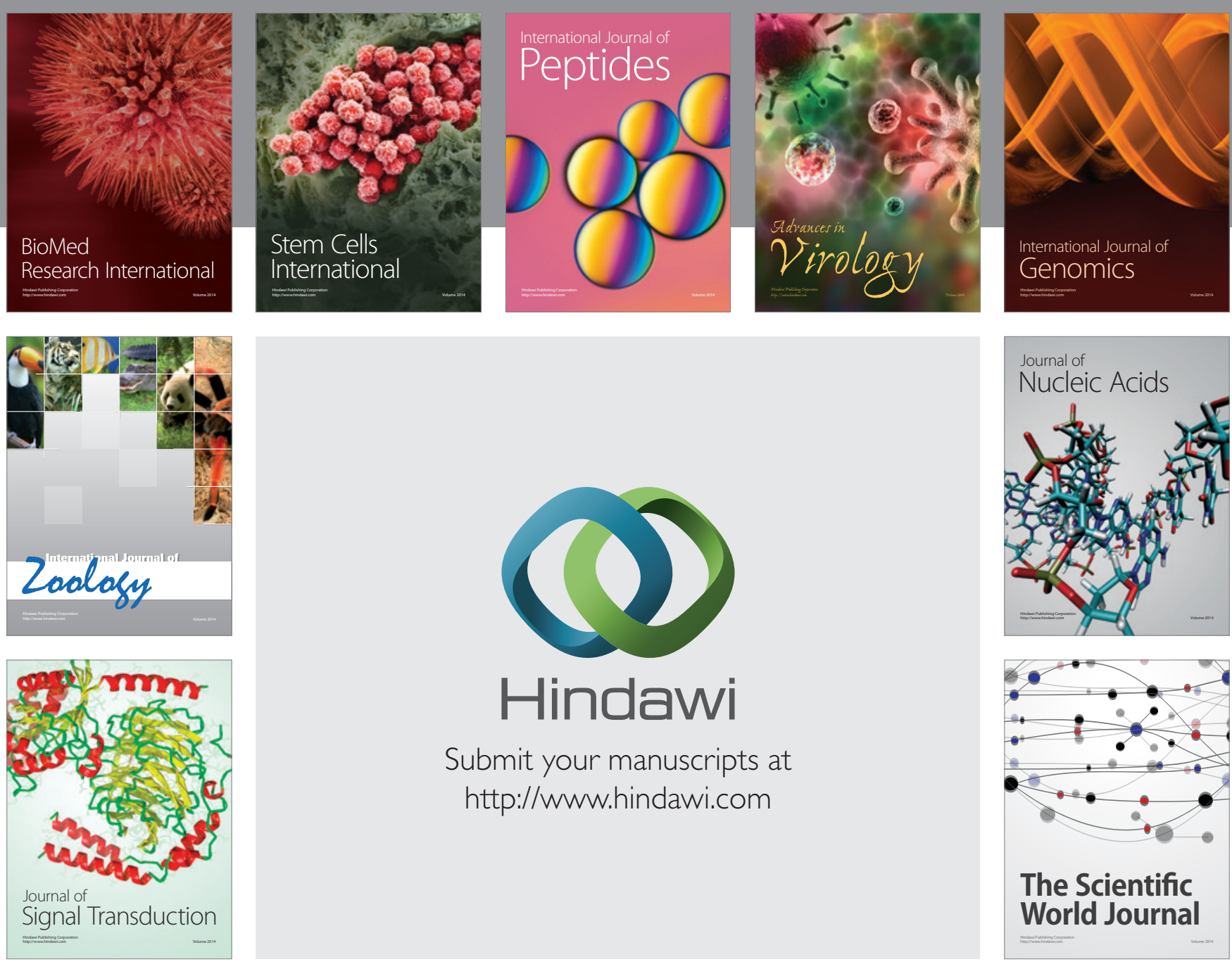

Submit your manuscripts at

http://www.hindawi.com
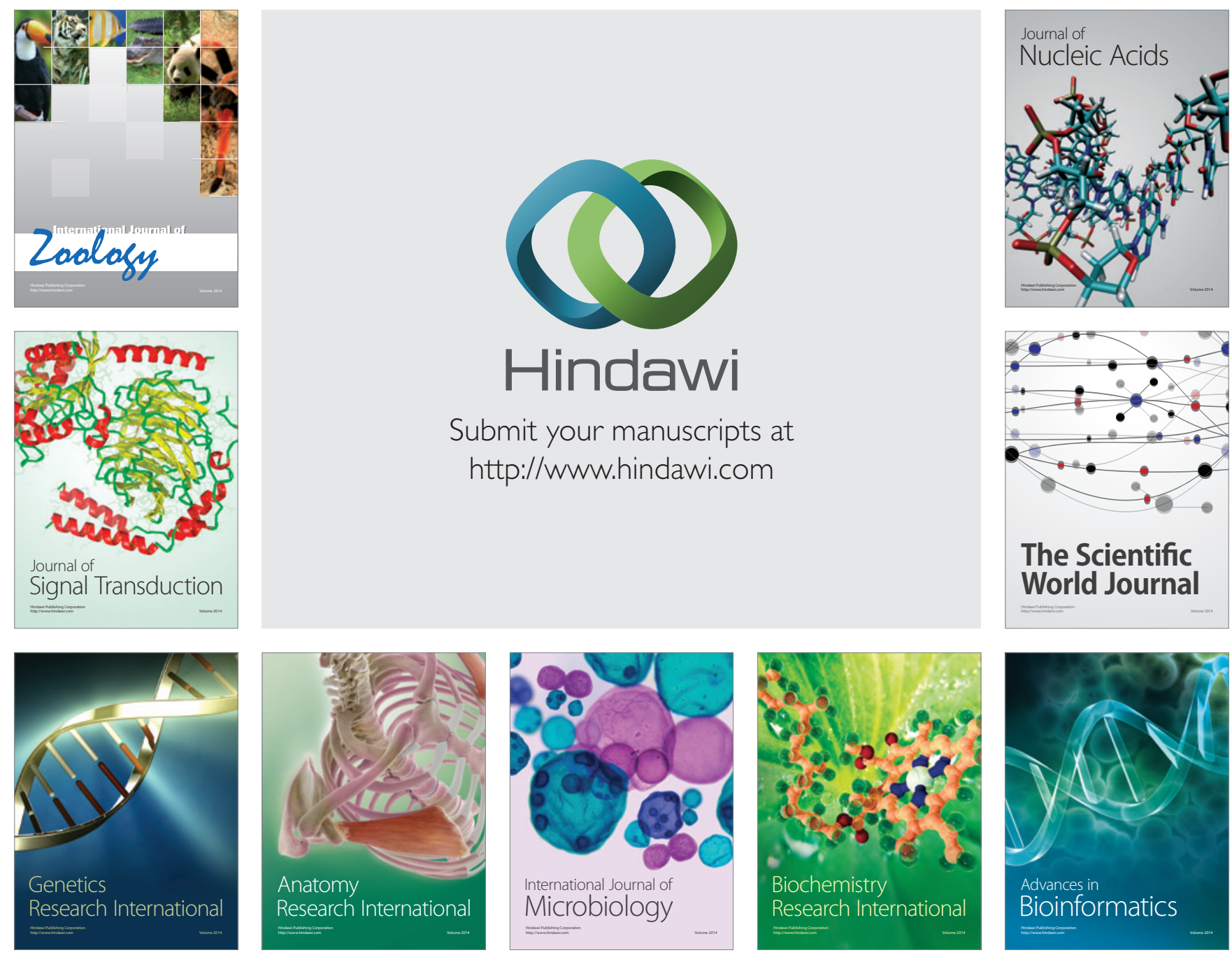

The Scientific World Journal
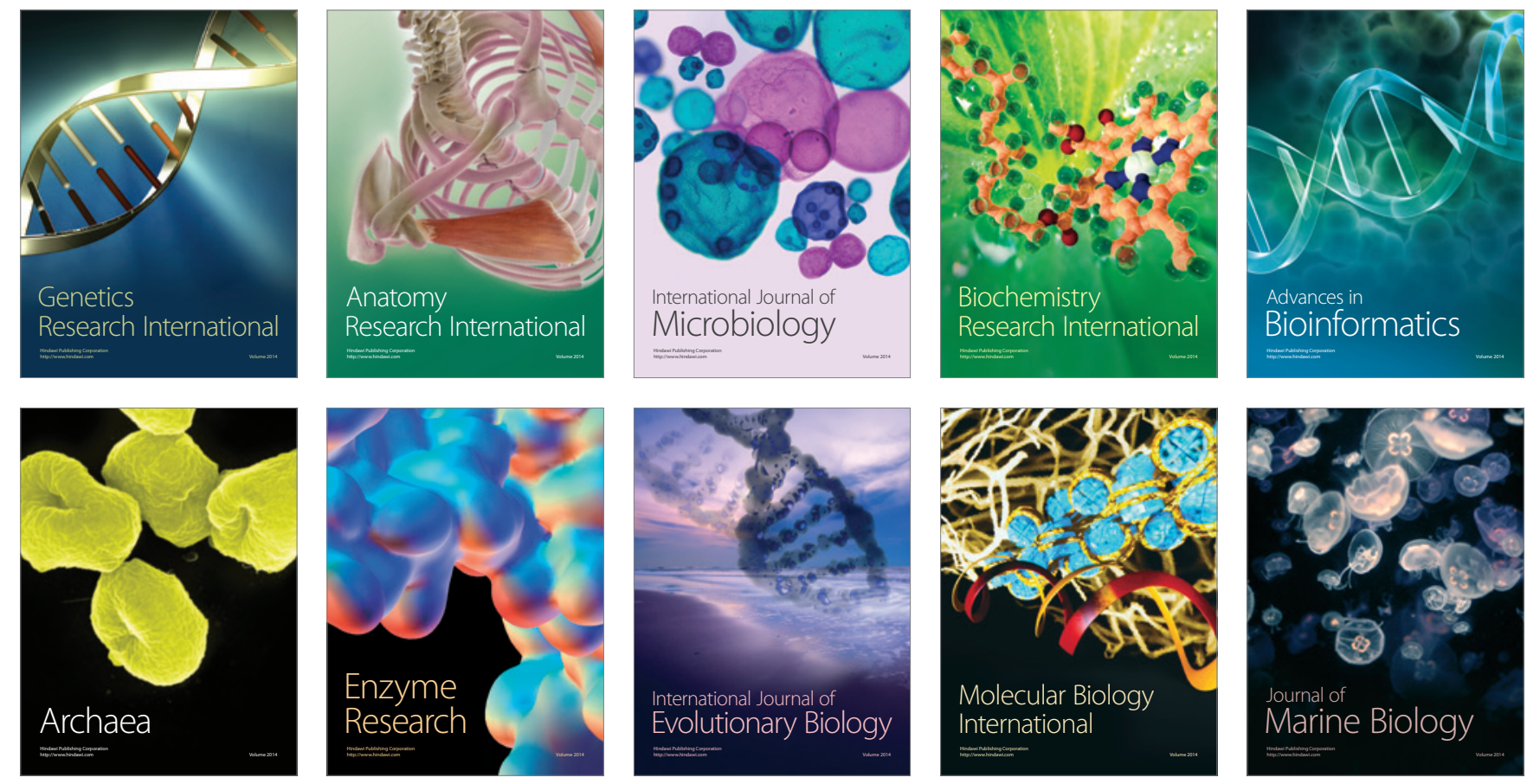